\title{
Erratum to: 'Acceleration rate of mitral inflow E wave: a novel transmitral doppler index for assessing diastolic function'
}

Roya Sattarzadeh ${ }^{1}$, Anahita Tavoosi ${ }^{*}$, Mostafa Jabbari ${ }^{1}$, Amir Farhang Zand Parsa ${ }^{1}$, Babak Geraiely ${ }^{1}$, Mohammad Saadat ${ }^{1}$, Farnoosh Larti ${ }^{1}$, Ali Pasha Meysamie ${ }^{2}$ and Mehrdad Salehi ${ }^{1}$

\section{Erratum}

Unfortunately, the original version of this article [1] contained an errors. Two corrections are with the author's name. In the metadata of the article Roya Sattarzadeh Badkoubeh was published instead of Roya Sattarzadeh. The second author's name recorded incorrectly was Babak Geraeli. This should be corrected to Babak Geraiely.

\section{Author details \\ ${ }^{1}$ Cardiology Department of Imam Khomeini Hospital, Tehran University of Medical Sciences, Tehran, Iran. ${ }^{2}$ Department of Community Medicine, Tehran University of Medical Sciences, Tehran, Iran.}

Received: 11 July 2016 Accepted: 11 July 2016

Published online: 26 July 2016

\section{Reference}

1. Sattarzadeh R, Tavoosi A, Jabbari M, Parsa AFZ, Geraiely B, Saadat M, Larti F, Meysamie AP, Salehi M. Erratum to: 'Acceleration rate of mitral inflow E wave: a novel transmitral doppler index for assessing diastolic function'. Cardiovasc Ultrasound. 2016;14:24.

\footnotetext{
*Correspondence: anahitatavoosi@gmail.com

${ }^{1}$ Cardiology Department of Imam Khomeini Hospital, Tehran University of Medical Sciences, Tehran, Iran

Full list of author information is available at the end of the article

Submit your next manuscript to BioMed Central and we will help you at every step:

- We accept pre-submission inquiries

- Our selector tool helps you to find the most relevant journal

- We provide round the clock customer support

- Convenient online submission

- Thorough peer review

- Inclusion in PubMed and all major indexing services

- Maximum visibility for your research

Submit your manuscript at www.biomedcentral.com/submit 